\title{
Inhibitory effect of bacterial antagonists on the growth of Macrophomina phaseolina (Tassi.) Goid. Causing charcoal rot of sunflower (Helianthus annus L.) invitro
}

\author{
A. Karmel Reetha ${ }^{* 1}$ and S. Mohan ${ }^{2}$ \\ ${ }^{1}$ Department of plant pathology, Vanavarayar Institute of Agriculture, Pollachi - 642103 Tamil Nadu, INDIA \\ ${ }^{2}$ Department of plant Pathology, Agricultural Collège and Research Institute, Madurai - 625104 Tamil Nadu, \\ INDIA \\ *Corresponding author. E-mail: reelee.pat@gmail.com \\ Received: February 2, 2015; Revised received: April 24, 2015; Accepted: June 20, 2015
}

\begin{abstract}
Charcoal rot caused by Macrophominaphaseolinais a major disease causing in sunflower plant. The pathogen invasion occurs from the seedling to maturity stage. To overcome this problem in vitro, sensitivity of $M$. phaseolina was determined through inhibition zone technique to various isolates of antagonistic bacteria like seven isolates of Pseudomonasfluorescens $\left(\mathrm{EPf}_{2}, \mathrm{EDPf}_{3}, \mathrm{APf}_{4}, \mathrm{CPf}_{5}, \mathrm{MPf}_{6}, \mathrm{KPf}_{7}\right.$ andPf $\left.\mathrm{Pf}_{1}\right)$ andseven isolates Bacillus subtilis $\left(\mathrm{EBs}_{1}, \mathrm{EDBs}_{2}, \mathrm{ABs}_{3}, \mathrm{CBs}_{4}, \mathrm{MBs}_{5}, \mathrm{KBs}_{6} \mathrm{andBs}_{10}\right)$ amended into PDA medium. The results showed that the entire bacterial antagonist were effective against the fungus $M$. phaseolina and exhibited appreciable amount of inhibition. Among these bacterial antagonistsignificantly compared to the control P.fluorescens (Pf1) proved to be the most effective (71.49\%) with an inhibition zone of $5.00 \mathrm{~mm}$ reducing the colony growth of $M$. Phaseolinafollowed $B$. subtilis (65.92\%)inhibition zone of $17.80 \mathrm{~mm}$ respectively over control. However, from these studies it is concluded that an isolate of various antagonist can vary in its sclerotia producing ability on root.
\end{abstract}

Keywords: Bacterial biocontrol, In-vitro, Macrophomina phaseolina, Sunflower

\section{INTRODUCTION}

Sunflower (Helianthus annus, L.) is an important oil seed crop in India popularly known as "Surajmukhi." The name "Helianthus" is derived from 'Helios' meaning 'sun' and 'anthos' meaning 'flower'. It is known as sunflower as it follows the sun by day, always turning towards its direct rays. It is one of the fastest growing plants which belong to family Asteraceae (Compositae) (Rodriguez et al.,2002). M. phaseolina the causal agent of charcoal rot is a serious threat for sunflower crop especially in the arid regions of the world (Hoes, 1985).

It has been estimated that diseases can cause an average annual loss of 12 per cent in yield from nearly 12 million hectares of the world (Zimmer and Hoes, 1978; Kolte, 1985). The fungus has a host specific behaviour and a high degree of variation in its morphological, cultural and pathological properties, even when it is isolated from different parts of the same plant (Khan, 2007). Bhuttaet al. (1995) studied the transmission process of M. phaseolinafrom root to upward growth of the sunflower and development of fungus establishment in the seedlings within 48 hours of entering in the host tissue. Shekhar et al. (2006) on the basis of colony colour, divided seven isolates of $M$. phaseolina into four groups namely greyish white, blackish grey, dark black and cottony white colonies Muhammad et al. (2010) observed that in dual culture assays, all antagonists inhibited the growth of $M$. phaseolina. Rhizobium melilotiand Bacillus subtilisshowed maximum inhibition in the growth of M. phaseolinain sunflower. Cook and Baker (1983) reported that the use of biological agent for the control of plant diseases is an alternative method of chemical control. Several disease management strategies are available viz., cultural, biological, resistant cultivars, crop rotation and chemical control (Kamal, 2006). The objective of the study was toisolate and identifydifferent isolates of pathogens isolates of antagonists from the rhizosphere region of sunflower root and; In vitro screening of different isolates of antagonists against $M$. phaseolina.

\section{MATERIALS AND METHODS}

Isolation of pathogen (M. phaseolina): The pathogen inciting root rot caused byM. phaseolinawas isolated from the diseased stems and roots of sunflower collected from different places of Tamil Nadu. The surface sterilized tissues were plated on potato dextrose agar (PDA)in sterile Petri plates and incubated at room temperature $\left(28 \pm 2{ }^{\circ} \mathrm{C}\right)$ for seven days.slants and sand maize media for further studies(Rangaswami, 1993).

Sand maize medium:

Broken maize or Maize Powder - $100 \mathrm{~g}$

Sieved white sand $\quad-1900 \mathrm{~g}$ 
Seven isolates of $M$. phaseolinacollected from various locations were multiplied on sand maize medium (sand and ground maize grains mixed in the ratio of 19:1, moistened and autoclaved in saline bottles at $201 \mathrm{~b}$ for two hours) and incubated at $28 \pm 2^{\circ} \mathrm{C}$ for 21 days.

Morphological characters of $M$. phaseolinaisolates: From the seven days old culture plates, nine mm disc of the pathogen was cut by using a sterilized cork borer and placed at the centre of the each sterile Petri dish containing $15 \mathrm{ml}$ of previously sterilized and solidified PDA medium. The plates were incubated at room temperature $\left(28 \pm 2^{0} \mathrm{C}\right)$ for five days. The growth and morphological characters of the isolates viz., colony morphology, mycelia growth rate, colony colour and shape of sclerotia were noted. The pycnidia were observed under microscope (magnification 45X) after calibration with ocular and stage micrometer (Fig 1).

Isolation of antagonists from the Rhizosphere

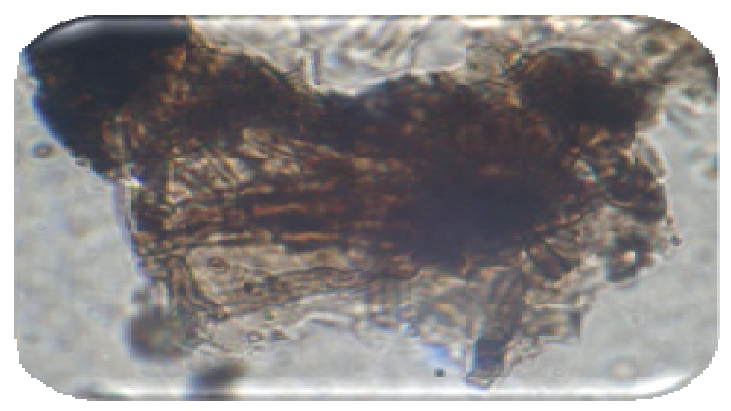

region: Antagonistic fungi and bacteria were isolated from the rhizosphere soil collected from different sunflower growing areas of Tamil Nadu (Table 2). The plants were pulled out gently with intact roots and the excess soil adhering on roots was removed gently. Ten gram of rhizosphere soil was transferred to $250 \mathrm{ml}$ Erlen Meyer flask containing $100 \mathrm{ml}$ of sterile distilled water. After thorough shaking, the antagonist in the suspension was isolated by serial dilution plate method. From the final dilutions of $10^{-3}, 10^{-4}, 10^{-5}$ and $10^{-6}$, one $\mathrm{ml}$ of each aliquot was pipetted out, poured in sterilized Petri dish containing King's B medium (King etal., 1954) and nutrient agar medium separately and they were gently rotated clockwise and anti-clockwise for uniform distribution and incubated at room temperature $\left(28 \pm 2^{0} \mathrm{C}\right)$ for 24 hours. Colonies with characteristics of Bacillus spp., Pseudomonas spp. were isolated individually and purified by streak plate method (Rangaswami,

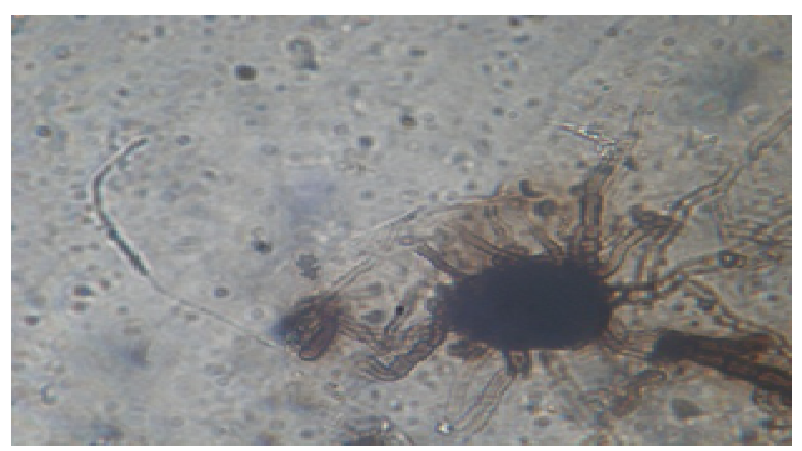

Fig. 1. Morphological character of Sunflower root rot. (a) Pycnidia (b) Micro sclerotia.

Table 1. Isolation of Biocontrol agents screened against M. Phaseolina.

\begin{tabular}{|c|c|c|c|c|}
\hline S. N. & Location & Crop & Source & Isolates code \\
\hline a) & \multicolumn{4}{|c|}{ Biocontrol agents isolated from different locations } \\
\hline I. & \multicolumn{4}{|l|}{ Bacillus spp. } \\
\hline 1. & Erur & Sunflower & Rhizosphere & $E B s_{1}$ \\
\hline 2. & Edaiyar & Sunflower & Rhizosphere & $E D B s_{2}$ \\
\hline 3. & Aruppukottai & Sunflower & Rhizosphere & $A B s_{3}$ \\
\hline 4. & TNAU & Sunflower & Rhizosphere & $C B s_{4}$ \\
\hline 5. & Madurai & Sunflower & Rhizosphere & $M B s_{5}$ \\
\hline 6. & Thoothukudi & Sunflower & Rhizosphere & $K B s_{6}$ \\
\hline II. & \multicolumn{4}{|l|}{ P. fluorescent } \\
\hline 1. & Erur & Sunflower & Rhizosphere & $E P f_{2}$ \\
\hline 2. & Edaiyar & Sunflower & Rhizosphere & $E D P f_{3}$ \\
\hline 3. & Aruppukottai & Sunflower & Rhizosphere & $A P f_{4}$ \\
\hline 4. & TNAU & Sunflower & Rhizosphere & $C P f_{5}$ \\
\hline 5. & Madurai & Sunflower & Rhizosphere & $M P f_{6}$ \\
\hline 6. & Thoothukudi & Sunflower & Rhizosphere & $K P f_{7}$ \\
\hline $\begin{array}{l}\text { b) } \\
\text { I. }\end{array}$ & \multicolumn{4}{|c|}{$\begin{array}{l}\text { Biocontrol agents obtained from other source } \\
\text { P.fluorescens }\end{array}$} \\
\hline i. & $P f_{l}$ & & \multirow{2}{*}{\multicolumn{2}{|c|}{ Department of Plant Pathology, TNAU, Coimbatore }} \\
\hline II & B.subtilis & & & \\
\hline i. & $B s_{10}$ & & \multicolumn{2}{|c|}{ Department of Plant Pathology, TNAU, Coimbatore } \\
\hline
\end{tabular}




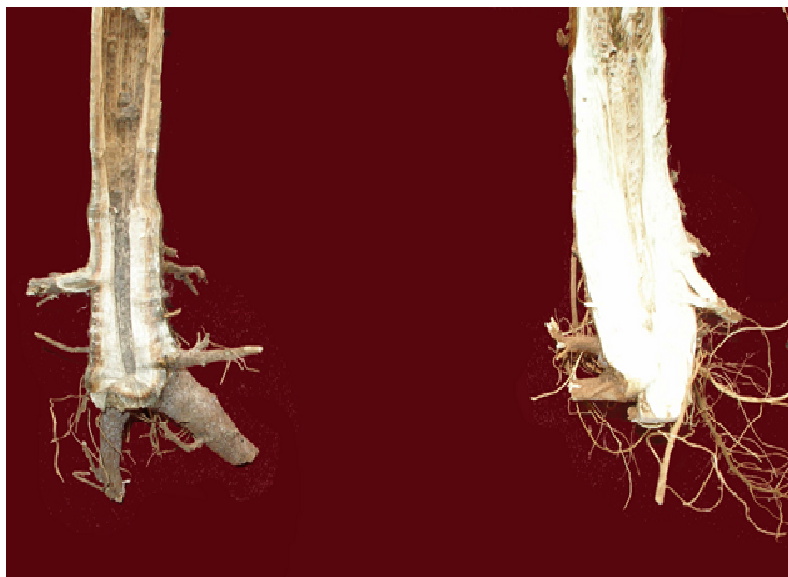

Fig 2. Symptoms of M. phaseolina in sunflower root.

1993) on nutrient agar medium and King's B medium. The pure cultures were maintained on the respective agar slants at $4^{\circ} \mathrm{C}$.

Screening of biocontrol agents in vitro: The antagonistic effect of the biocontrol agent'sviz., seven isolates in each of fluorescenspseudomonas and Bacillusspp were tested against $M$. phaseolinaby dual culture technique (Dennis and Webster, 1971). Five-mm-diamycelial disc of $M$. phaseolinawas placed at one end of the Petri plate containing PDA and the bacterial antagonist were streaked at the opposite end each of the Petri plates. Inoculation of $M$. phaseolina without antagonists served as control and each treatment was replicated three times. When the fungus attained full growth in the control plate, growth of the pathogen and inhibition zone were measured and per cent reduction in growth over control was calculated.
After four days of incubation, mycelia growth of the pathogen and inhibition zone was measured in treated as well as control plates. Per cent inhibition (PI) of mycelia growth was calculated using the formula suggested by Pandeyet al. (2000).

$$
P I=\frac{\mathrm{De}-\mathrm{Dt}}{\mathrm{De}} \times 100
$$

De - average diameter of fungal growth $(\mathrm{cm})$ in control $\mathrm{Dt}$ - average diameter of fungal growth $(\mathrm{cm})$ in treatment Statistical analysis: The experiments were conducted by Completely Randomized Design (CRD). The percentage values were transformed into "Arcsine" and "Square -root". The statistical analysis of the experiment was done by following the methods suggested by Gomez and Gomez (1984). Per cent values were transformed by arcsine or square root transformation.

\section{RESULTS AND DISCUSSION}

Symptoms of sunflower charcoal rot (M. phaseoliina): The symptoms of sunflower root rot incidence observed in different location were examined. In general the disease occurred during flowering to maturity stage. At this stage, roots were turn into dark brown external, inner tissues appeared greyish because of the large number of sclerotia embedded in them. The stem had silvery grey discoloration extending up from the base, and in many cases, the epidermis was split, the roots were black and mostly decomposed (Fig. 2). $M$. phaseolinasoil borne species which infect root, stem and collar region of plant host and caused cortical and vascular discoloration, was prevalent in arid regions,

Table 2. Effect of bacterial antagonists on the growth of M. Phaseolina.

\begin{tabular}{|c|c|c|c|c|}
\hline S. N. & Isolates & $\begin{array}{l}\text { Mycelial growth } \\
\text { (cm)* } 7 \text { DAI* }\end{array}$ & $\begin{array}{c}\text { Inhibition over } \\
\text { Control }(\%)\end{array}$ & $\begin{array}{c}\text { Inhibition zone } \\
(\mathrm{mm})\end{array}$ \\
\hline 1. & $\mathrm{Pf}_{1}$ & 2.56 & 71.49 & 5.00 \\
\hline 2. & $\mathrm{EPf}_{2}$ & 4.70 & 47.66 & 2.00 \\
\hline 3. & $\mathrm{EDPf}_{3}$ & 5.26 & 41.42 & 1.00 \\
\hline 4. & $\mathrm{APf}_{4}$ & 4.30 & 52.11 & 4.20 \\
\hline 5. & $\mathrm{CPf}_{5}$ & 3.20 & 64.36 & 1.00 \\
\hline 6. & $\mathrm{MPf}_{6}$ & 6.13 & 31.73 & 2.10 \\
\hline 7. & $\mathrm{KPf}_{7}$ & 6.36 & 29.17 & 2.20 \\
\hline 8. & $\mathrm{Bs}_{10}$ & 3.06 & 65.92 & 17.80 \\
\hline 9. & $\mathrm{EBs}_{1}$ & 6.33 & 29.51 & 5.20 \\
\hline 10. & $\mathrm{EDBs}_{2}$ & 6.10 & 32.07 & 4.10 \\
\hline 11. & $\mathrm{ABs}_{3}$ & 5.86 & 34.74 & 1.50 \\
\hline 12. & $\mathrm{CBs}_{4}$ & 3.30 & 63.25 & 2.30 \\
\hline 13. & $\mathrm{MBs}_{5}$ & 4.56 & 49.22 & 13.10 \\
\hline 14. & $\mathrm{KBs}_{6}$ & 5.70 & 36.52 & 2.10 \\
\hline 15. & Control & 8.98 & - & - \\
\hline
\end{tabular}


but can be found in moderate climates when high temperature and dry conditions occur in sunflower by Sonja et al. (2012).

Inhibitory effect of bacterial antagonists on the growth of $M$. phaseolina: Preliminary screening to identify best antagonist among the fourteen bacterial antagonists was conducted in vitro. The result showed that the entire bacterial antagonist were effective against the fungus $M$. phaseolina and exhibited appreciable amount of inhibition.

Among the seven isolates of $P$. fluorescens Pf1 allowed minimum mycelial growth of $M$. phaseolina $2.56 \mathrm{~cm}$ with 71.49 per cent growth reduction and with an inhibition zone of $5.00 \mathrm{~mm}$ followed by $\mathrm{CPf}_{5}$ minimum mycelial growth of $3.20 \mathrm{~cm}$ with 34.36 per cent growth reduction and with an inhibition zone of $1.00 \mathrm{~mm}$ (Table. 2). Pseudomonas spp. showed antifungal activity against the alfalfa pathogen $M$. phaseolina inthe in-vitro as well as in the in-vivo assays (Guinazuet al., 2012).

Among the seven Bacillus isolates $\mathrm{Bs}_{10}$ allowed minimum mycelial growth of $3.06 \mathrm{~cm}$ with 65.92 per cent growth reduction and inhibition zone of $17.80 \mathrm{~mm}$ (Table. 2) followed by $\mathrm{CBs}_{4} 3.30 \mathrm{~cm}$ with 63.25 per cent growth reduction and inhibition zone of $2.30 \mathrm{~mm}$. The control Petri dish received maximum mycelial growth of $8.98 \mathrm{~cm}$ within seven days after inoculation.Priyadharshni (2012) reported that the dual culture in blackgram antagonist B. subtilis $\left(\mathrm{MB}_{3}\right)$ inhibited the growth of $M$. phaseolina which recorded the mycelia diameter of $4.8 \mathrm{~cm}$ and it leads to 42.06 per cent of inhibition over control.

\section{Conclusion}

The present study was successful in selecting effective isolates of bio control agent like P.fluorescens and B.subtilis. The results on in vitro antagonistic effect against $M$. phaseolina was maximum with Pfl, followed by $\mathrm{Bs}_{10}$ comparison of the control Petri dish received maximum mycelial growth of $8.98 \mathrm{~cm}$ within seven days after inoculation.Even though today numerous different strategies have been employed to prevent plant diseases, evidence has shown that harnessing indigenous or introduced soil microbial inoculants influence plant health and productivity.

\section{ACKNOWLEDGEMENTS}

The authors are grateful to the Head, Department of Agricultural Biotechnology, S.V.P. University of Agriculture and Technology Meerut, Uttar Pradesh for providing the necessary facilities for conducting this research work.

\section{REFERENCES}

Bhutta, A.R., S.I. Ahmad and M.H.Rehber-Bhatti.1995. Oilseed industry development in Pakistan.Sci Tech \& Development. 14:20-26.

Cook, R.J., and K.F. Baker. (1983). The nature and practice of biological control of plant pathogens. The American Phytopathological Society.p. 539.

Dennis, C. and J. Webster. (1971). Antagonistic properties of species groups of TrichodermaI. Production of non-volatile antibiotics. Trans Br Mycol Soc., 57: 25-39.

Gomez, K.A.,and A.A. Gomez. (1984). Statistical procedures for Agricultural Research.John Wiley and Sons, New York p. 680.

Guinazu, L.B., J.A. Andres, M. Rovera and S.B. Rosas. (2012). Isolation and characterization of rhizobacteria antagonistic to Macrophominaphaseolina (Tassi) Goid. causal agent of alfalfa damping- off.Environmental Protection Strategies for Sustainable Development, Pp.329-339.

Hoes, J.A. (1985). Macrophominaphaseolinacausal agents of charcoal rot of sunflower and other crops. Agri. Res. Station Modern Manitoba.58: 209-219.

Kamal, K.P. (2006). Biological Control.The Plant Health Instructor. P.1

Khan, S.N. (2007). Macrophominaphaseolina as causal agent for charcoal rot of sunflower. Mycopathologia, 5 (2):111-118.

Kolte, S.J. (1985). Sunflower diseases of annual oilseed crops, Vol. III, CRC Press,Inc Boca Raton, Florida, pp. 33-44.

Muhammad, A., A. Waseemand M. Javedzaki. (2010). Bio efficacy of microbial antagonist against Macrophomina phaseolina on sunflower.Pak. J. Bot.,42(4):2935-2940.

Pandey, K.K.,P.K. Pandeyand J.P.V. Upadhyay. (2000). Selection of potential isolate of biocontrol agents based on biomass production, growth rate and antagonistic capability. Veg. Sci., 27: 194-196.

Priyadharshni, B. (2012). Management of blackgram root rot caused by M. phaseolina(Tassi.) Goid.by using Bacillus subtilis. M.Sc. (Ag.) Thesis,TNAU, Coimbatore p. 107-119.

Rangaswami, G. (1993). Diseases of crop plants in India. Prentice Hall of India (Pvt). Ltd., New Delhi P 498

Rodriguez, J.D., J. de, R. Romero-Garcia and J.L.A. Rodriguez -Garcia. (2002). Characterization of proteins from sunflower leaves and seeds. Relationship of biomass and seed yield. In: Janich, J. and A. Whikey. (Eds). Trends in New Crops and New Uses. ASHS press, Alexandria, pp. 143-149.

Shekhar, M., R.C. Sharma, S.Lokendra and D. Ram. (2006). Morphological and pathogenic variability of Macrophomina phaseolina (Tassi.) Goidincitant of charcoal rot of maize in India. IndianPhytopathol., 59(4):453-459.

Sonja, T., D. Boško, D. Aleksandra, T. Sreten and J. Siniša. (2012). Bio ecological relations of sunflower pathogens - Macrophomina phaseolinaand Fusarium spp. and sunflower tolerance to these pathogen. Romanian Agric. Res., 29.

Zimmer, D.E. and J.A. Hoes. (1978). Disease, In: Sunflower Science and Technology, Agronomy 19 (Ed. by J.F. Carter) pp. 255-25. 